\begin{tabular}{l|ll} 
J B E & $\mid \begin{array}{ll}\text { JOURNAL OF } \\
\text { BIOLOGY }\end{array}$ & $\begin{array}{l}\text { E-ISSN 2656-3436/ P-ISSN 2615-3947 } \\
\text { IAIN KUDUS } \\
\text { Tersedia online: http://journal.iainkudus.ac.id/index.php/jbe }\end{array}$ \\
\hline
\end{tabular}

\title{
Studi Kompetensi Pedagogik Calon Guru Biologi Di UIN Raden Intan Lampung dan Kaitannya dengan Pemahaman Terhadap Perkembangan Peserta Didik
}

\author{
Wanda Agus Prasetya ${ }^{1}$, Supriyadi ${ }^{2}$ \\ Universitas Islam Negeri Raden Intan Lampung ${ }^{1,2}$, \\ wanda.prasetya.5@gmail.com ${ }^{1}$, supriadi @ radenintan.ac.id²
}

\begin{abstract}
ABSTRAK
Penelitian ini bertujuan untuk mengungkap profil kompetensi pedagogik mahasiswa calon guru Pendidikan Biologi UIN Raden Intan Lampung dan menelisik pemahaman perkembangan peserta didik mahasiswa calon guru Pendidikan Biologi UIN Raden Intan Lampung, serta menganalisis hubungan kompetensi pedagogik mahasiswa calon guru Pendidikan Biologi UIN Raden Intan Lampung dengan pemahaman perkembangan peserta didik, yang meliputi: persiapan kegiatan pembelajaran yang mendidik, pengembangan potensi peserta didik, dan komunikasi peserta didik. Metode penelitian yang diterapkan yakni penelitian kualitatif menggunakan metode deskriptif. Sampel penelitian ini adalah mahasiswa calon guru Pendidikan Biologi UIN Raden Intan Lampung yang dipilih dengan menggunakan teknik pengambilan sampel Sampling purposive. Sampel yang digunakan adalah mahasiswa calon guru biologi UIN Raden Intan Lampung yang telah mengambil program mata kuliah Evaluasi Pembelajaran, Telaah Kurikulum, Pengembangan Kurikulum, dan Microteaching, serta bersedia menjadi informan di dalam penelitian ini. Instrumen penelitian yang digunakan yakni observasi, wawancara, dokumentasi dan Uji Kompetensi Guru (UKG). Uji keabsahan data menggunakan triangulasi, sedangkan teknis analisis data yang digunakan pada penelitian antara lain reduksi data, penyajian data, dan verification. Hasil penelitian menunjukkan bahwa Profil kompetensi pedagogik mahasiswa calon guru biologi di UIN Raden Intan Lampung menunjukkan kriteria cukup dengan nilai rata-rata akhir sebesar 54,42. Pemahaman perkembangan peserta didik oleh mahasiswa calon guru biologi di UIN Raden Intan Lampung menunjukkan kriteria cukup dengan nilai rata-rata akhir sebesar 55,95. Dapat ditafsirkan terdapat hubungan/ keterkaitan antara kompetensi pedagogik guru terhadap pemahaman calon guru mengenai perkembangan peserta didiknya. Bahwa semakin baik kompetensi pedagogik mahasiswa calon guru, maka semakin baik pula pemahaman mahasiswa calon guru terhadap perkembangan peserta didiknya, sebaliknya jika semakin tidak baik kompetensi pedagogik mahasiswa calon guru, maka semakin tidak baik pula pemahaman mahasiswa calon guru terhadap perkembangan peserta didiknya.
\end{abstract}

Kata kunci: Calon guru, Kompetensi pedagogik, Perkembangan peserta didik. 


\begin{abstract}
This study aims to uncover the pedagogical competency profile of Biology Education teacher candidates at UIN Raden Intan Lampung and to investigate the understanding of the development of Biology Education student candidates for Biology Education at UIN Raden Intan Lampung, as well as to analyze the relationship between the pedagogical competences of Biology Education teacher candidates at UIN Raden Intan Lampung and the understanding of development. students, which includes: preparation of educational learning activities, development of the potential of students, and student communication. The research method applied is qualitative research using descriptive methods. The samples of this research were students of Biology Education teacher candidates at UIN Raden Intan Lampung who were selected using purposive sampling technique. The sample used is the biology teacher candidate at UIN Raden Intan Lampung who has taken the course of Learning Evaluation, Curriculum Analysis, Curriculum Development, and Microteaching, and is willing to be informants in this research. The research instruments used were observation, interviews, documentation and the Teacher Competency Test (UKG). The data validity test used triangulation, while the data analysis techniques used in the study included data reduction, data presentation, and verification. The results showed that the pedagogic competency profile of biology teacher candidate students at UIN Raden Intan Lampung showed sufficient criteria with a final average score of 54.42. The understanding of the development of students by prospective biology teacher students at UIN Raden Intan Lampung shows sufficient criteria with a final average score of 55.95. It can be interpreted that there is a relationship / linkage between teacher pedagogical competences and the understanding of prospective teachers regarding the development of their students. Whereas the better the pedagogical competence of prospective teacher students, the better the understanding of prospective teacher students on the development of their students, on the other hand, if the pedagogical competence of prospective teacher students is not good, the understanding of student teacher candidates will be poorer.
\end{abstract}

Key words: Prospective teachers, pedagogic competence, student development.

\title{
PENDAHULUAN
}

Terkait pembelajaran, kompetensi guru sangat penting karena guru bertanggung jawab kepada peserta didik untuk mengubahnya dari tidak bisa menjadi bisa, dari yang awalnya tidak mengerti menjadi mengerti, dan dari yang tidak yakin menjadi yakin. Untuk itu, seorang guru harus memiliki kompetensi yang utuh, yang mencakup aspek pengetahuan, keterampilan, dan perilaku. Dengan demikian, berarti seorang guru harus memiliki kualitas yang baik.

Pendidik atau guru dalam menjalankan tugasnya wajib memiliki kompetensi guru, sebab tugas utama guru tidak hanya mentransfer ilmu kepada peserta didik tetapi, mendidik, 
mengarahkan, menilai, mengevaluasi, dan memberikan stimulus supaya potensi yang dimiliki peserta dididk dapat dikembangkan untuk berinovasi. Peran guru sangat besar dalam pembelajaran, maka seyogyanya guru harus memiliki kompetensi yang tinggi agar dapat melakukan pembelajaran efektif sehingga peserta didik dapat termotivasi untuk belajar.

Merujuk PP No.19 Tahun 2005 Pasal 28 Ayat 3 dan UU No.14 Tahun 2005 Pasal 10 Ayat 1, menjelaskan bahwa kompetensi seorang pendidik sebagai penyalur pengkajian pada tingkatan anak usia dini, pendidikan dasar dan menengah yang mencakup: kompetensi pedagogik, kompetensi kepribadian, kompetensi profesional, dan kompetensi sosial (Sagala, 2009). Dengan memiliki 4 kompetensi tersebut seorang guru diharapkan mampu memahami interaksi belajar mengajar dan mengaplikasikannya ke dalam proses interaksi belajar mengajar serta proses pemahaman perkembangan peserta didik.

Satu diantara kompetensi pedagogik guru yaitu menguasai karakteristik peserta didik, betapa sangat pentingnya bahwa seorang guru sebelum melakukan pembelajaran harus mengetahui, memahami, dan menghayati satu persatu karakteristik peserta didiknya guna menentukan pemilihan strategi, media dan evluasi. Pada hakikatnya peserta didik memiliki perbedaan yang begitu luas, salah satunya perbedaan intelektual. Ada peserta didik yang cerdas, tetapi ada juga yang kurang cerdas atau bahkan sangat kurang cerdas. Ada yang dapat dengan segera memecahkan masalah-masalah yang berkaitan dengan pekerjaan intelektual, tetapi ada yang lambat atau bahkan tidak mampu mengatasi suatu masalah yang mudah sekalipun. Dari uraian tersebut, jelas bahwa penguasaan karakteristik peserta didik menjadi pertimbangan dalam menentukan pemilihan strategi, media dan evaluasi (Irwantoro and Suryana, 2016).

Menurut Panda, kompetensi pedagogik guru merupakan sebuah kemampuan serta keinginan yang secara reguilar menerapkan sikap, pengetahuan, dan keahlian- keahlian untuk mempromosikan pembelajaran dari guru dan murid (Tyagita and Iriani, 2018). Oleh sebab itu, Pendidik memiliki tugas tentunya tidak hanya sebatas mengajar saja, tetapi juga seorang pendidik harus mampu memahami masing-masing karakteristik peserta didiknya, agar dalam proses pembelajaran dapat memudahkan guru dalam menyesuaikan materi yang akan diajarkan kepada peserta didik sesuai karakteristik masing-masing peserta didik (Musfah, 2018). 
Sebagai calon guru atau pendidik, mahasiswa tentu harus menambah kekayaan pemahaman pada dirinya mengenai syarat dan prasyarat untuk menjadi seorang pendidik yang ideal sehingga dapat menciptakan generasi bangsa yang cerdas sesuai dengan tujuan yang termaktub dalam UUD 1945. Begitu juga sebagai pihak yang memiliki amanah untuk mempertanggung jawabkan atas keberhasilan dalam mengajar, pendidik dituntut untuk mampu dalam mempersiapkan dan melakukan penilaian dengan baik, sehingga tujuan dari pembelajaran yang telah dirumuskan dapat terlaksana dengan baik. Selain itu, hasil dari dilaksanakannya evaluasi pembelajaran peserta didik dapat dijadikan barometer kinerja pendidik. Hasil dari penilaian bukan hanya bermanfaat bagi pendidik semata, tetapi bagi peserta didik. Dalam hal ini, peserta didik bisa mengetahui hasil kinerjanya setelah menerima pelajaran dan arahan dari pendidik.

Mahasiswa sebagai calon guru atau pendidik harus mempersiapkan dalam menguasai kompetensi keguruan, yang salah satunya melalui program pembelajaran microteaching. Menurut Hidayah pembelajaran microteaching merupakan suatu program pelatihan untuk menyiapkan mahasiswa agar menguasai kompetensi keguruan, sehingga dapat mengemban tugas dan tanggung jawab secara profesional (Sukmawati, 2019). Pentingnya pembelajaran ini sebagai kegiatan berlatih dalam menguasai keterampilan dasar mengajar yang merupakan proses pembelajaran yang dilakukan secara sederhana dan singkat dalam bagian demi bagian dengan kontrol yang cermat. Tiap bagian dilakukan secara cermat dan tepat sehingga diperoleh kemampuan tuntas dan optimal.

Kompetensi guru di Provinsi Lampung masih di bawah standar, berdasarkan data yang diperoleh dari Neraca Pendidikan Daerah, rata-rata nilai UKG sebesar 53,38 dan nilai kompetensi pedagogiknya sebesar 49,44. Melihat ujian kompetensi tersebut maka pendidik harus lebih meningkatkan kompetensinya (Kemendikbud, 2020). Disisi lain tentunya tidak hanya pendidik/ guru saja yang harus meningkatkan kompetensinya, tetapi mahasiswa calon pendidik/ guru juga harus lebih meningkatkan kompetensinya, guna mempersiapkan kekayaan pemahaman, pengetahuan dan keterampilan dalam dirinya sehingga nantinya dapat menjadi pendidik/ guru yang ideal.

Perkembangan individu setiap peserta didik berbeda-beda, menurut dasar atau pandangan yang digunakan dalam melihat perkembangan individu. Tahap perkembangan 
individu ada yang dilihat berdasarkan aspek perkembangan biologis, aspek perkembangan kognitif, aspek perkembangan afektif, aspek didaktis dan aspek-aspek lainnya. Dengan demikian, pembagian fase-fasenya juga akan berbeda-beda sesuai dengan pandangan yang diambil (Sutirna, 2013). Menurut Havighurst berpendapat bahwa perkembangan tersebut dinyatakan sebagai tugas yang harus dipelajari, dikuasi dan dijalani oleh setiap individu dalam perjalanan kehidupannya (Sunarto and Hartono, 1995). Sedangkan menurut Wiitiam Siem, perkembangan dipengaruhi oleh pembawaan dan lingkungan yang artinya lingkungan termasuk pendidikan yang sangat berpengaruh pada perkembangan pertumbuhan, begitu pula dengan faktor genetik (Hidayah, 2009).

Berkaitan hal tersebut, proses pemahaman perkembangan peserta didik oleh guru harus selalu dilakukan, karena idealnya seorang guru salah satunya adalah faham sejauh mana perkembangan peserta didiknya. Jika seorang guru sudah faham akan perkembangan peserta didik, proses pembelajaran akan lebih mudah dilakukan, sebab guru akan mengetahui letak ruang fikiran yang kosong pada masing-masing peserta didiknya sehingga proses penambalan dalam pembelajaran akan lebih dapat optimal. Sebaliknya jika seorang guru tidak faham akan perkembangan peserta didiknya, otomatis proses evaluasi pembelajaran akan sulit dilakukan, karena guru tersebut tidak tahu letak ruang fikiran yang kosong manakah yang akan di tambal pada peserta didik.

Melihat kondisi ini maka perlu dilakukan evaluasi pemahaman mahasiswa calon guru biologi terhadap kompetensi pedagogik dan perkembangan peserta didik. Evaluasi ini dilakukan untuk mengetahui seberapa besar kemampuan mahasiswa calon guru dalam memahami kompetensi pedagogik dan pemahaman perkembangan peserta didik. Dari evaluasi ini kemudian dapat dimanfaatkan sebagai masukan yang nyata kepada dunia pendidikan, khususnya kepada mahasiswa calon guru dalam mempersiapkan kekayaan pemahaman, pengetahuan dan keterampilan dalam dirinya, sehingga nantinya dapat menjadi guru yang ideal. Berangkat dari pemaparan penulis di atas, penulis tertarik mengungkap kompetensi pedagogik mahasiswa calon guru Pendidikan Biologi UIN Raden Intan Lampung. 


\section{METODE PENELITIAN}

Metode penelitian yang diterapkan yakni penelitian kualitatif menggunakan metode deskriptif. Sampel penelitian ini adalah mahasiswa calon guru Pendidikan Biologi UIN Raden Intan Lampung yang dipilih dengan menggunakan teknik pengambilan sampel Sampling purposive. Sampling purposive merupakan teknik penentuan sampel dengan pertimbangan tertentu (Sugiono, 2011). Sampel yang digunakan adalah mahasiswa calon guru biologi UIN Raden Intan Lampung yang telah mengambil program mata kuliah Evaluasi Pembelajaran, Telaah Kurikulum, Pengembangan Kurikulum, dan Microteaching, serta bersedia menjadi informan di dalam penelitian ini. Instrumen penelitian yang digunakan yakni observasi, wawancara, dokumentasi dan Uji Kompetensi Guru (UKG). Uji keabsahan data menggunakan triangulasi, sedangkan teknis analisis data yang digunakan pada penelitian antara lain reduksi data, penyajian data, dan verification.

\section{HASIL DAN PEMBAHASAN}

Berdasarkan penelitian yang telah dilakukan maka didapatkan data meliputi : 1. Data hasil dari instrumen observasi, 2. Data hasil dari instrumen wawancara, 3. Data hasil dari instrumen dokumentasi, dan 4. Data hasil dari tes Uji Kompetensi Guru (UKG). Hasil penelitian ini disajikan dalam bentuk uraian dan tabel yang dideskripsikan secara rinci di bawah ini:

\section{Tabel 1}

\section{Data Hasil Observasi Kompetensi Pedagogik Dan Pemahaman Perkembangan Peserta didik Oleh Mahasiswa Calon Guru Pendidikan Biologi UINRaden Intan Lampung}

\begin{tabular}{c|l|c|c}
\hline No. & \multicolumn{1}{|c|}{$\begin{array}{c}\text { INDIKATOR KOMPETENSI } \\
\text { PEDAGOGIK }\end{array}$} & $\begin{array}{c}\text { RATA-RATA } \\
\text { JAWABAN (YA) }\end{array}$ & $\begin{array}{c}\text { RATA-RATA } \\
\text { JAWABAN } \\
\text { (TIDAK) }\end{array}$ \\
\hline 1. & Menguasai karakteristik peserta didik & 65,48 & 34,52 \\
\hline 2. & $\begin{array}{l}\text { Menguasai teori belajar dan prinsip- } \\
\text { prinsip pembelajaran yang mendidik }\end{array}$ & 48,57 & 51,43 \\
\hline 3. & Mengembangkan kurikulum & 75 & 25 \\
\hline 4. & Kegiatan pembelajaran yang mendidik & 56,43 & 43,58 \\
\hline 5. & Mengembangkan potensi peserta didik & 51,19 & 48,81 \\
\hline 6. & Komunikasi dengan peserta didik & 55,71 & 37,14 \\
\hline 7. & Penilaian dan evaluasi & 48,81 & 51,19 \\
\hline \multicolumn{2}{r}{ Rata-rata } & 57,31 & 41,67 \\
\hline
\end{tabular}




\begin{tabular}{c|c|c|c}
\hline No. & $\begin{array}{c}\text { INDIKATOR PERKEMBANGAN } \\
\text { PESERTA DIDIK }\end{array}$ & $\begin{array}{c}\text { RATA-RATA } \\
\text { JAWABAN (YA) }\end{array}$ & $\begin{array}{c}\text { RATA-RATA } \\
\text { JAWABAN } \\
\text { (TIDAK) }\end{array}$ \\
\hline 1. & Kognitif, Afektif, dan Psikomotorik & 55,95 & 44,05 \\
\hline
\end{tabular}

Tabel 2

\section{Data Hasil Wawancara Via Daring Kompetensi Pedagogik Dan Pemahaman Perkembangan Peserta didik Oleh Mahasiswa Calon Guru Pendidikan Biologi UIN Raden Intan Lampung}

\begin{tabular}{|c|c|c|}
\hline No. & $\begin{array}{l}\text { INDIKATOR } \\
\text { KOMPETENSI } \\
\text { PEDAGOGIK } \\
\end{array}$ & KESIMPULAN \\
\hline 1. & $\begin{array}{l}\text { Menguasai karakteristik } \\
\text { peserta didik }\end{array}$ & $\begin{array}{l}\text { Data hasil wawancara yang sudah dilakukan menunjukkan } \\
\text { kesimpulan bahwa dalam memahami karakteristik peserta } \\
\text { didik yaitu dengan cara pendekatan secara intensif, kemudian } \\
\text { mengamati tingkah laku peserta didik saat proses } \\
\text { pembelajaran berlangsung, saat sedang berdiskusi, tugas } \\
\text { kelompok, ketika diberi kesempatan bertanya, menjawab } \\
\text { atau memberi kesimpulan terkait materi yang diajarkan. }\end{array}$ \\
\hline 2. & $\begin{array}{l}\text { Menguasai teori belajar } \\
\text { dan prinsip-prinsip } \\
\text { pembelajaran yang } \\
\text { mendidik }\end{array}$ & $\begin{array}{l}\text { Mahasiswa calon guru pendidikan biologi dalam } \\
\text { pemahamannya terhadap teori belajar dan prinsip-prinsip } \\
\text { pembelajaran mengatakan satu kesatuan yang saling } \\
\text { berhubungan. Cara untuk memahami teori dan prinsip } \\
\text { pembelajaran dikaitkan dengan tujuan yang sebenarnya akan } \\
\text { dicapai dalam pembelajaran itu sendiri. Mahasiswa calon } \\
\text { guru dalam mengaplikasikan dan segi pemahaman memiliki } \\
\text { keselarasan yang cukup. }\end{array}$ \\
\hline 3. & $\begin{array}{l}\text { Mengembangkan } \\
\text { kurikulum }\end{array}$ & $\begin{array}{l}\text { Mahasiswa calon guru dalam proses pembelajaran di dalam } \\
\text { kelas menyediakan RPP dan melaksanakan kegiatan } \\
\text { pembelajaran sesuai isi serta mengkaitkannya dengan } \\
\text { konteks kehidupan sehari-hari peserta didik. }\end{array}$ \\
\hline 4. & $\begin{array}{l}\text { Kegiatan pembelajaran } \\
\text { yang mendidik }\end{array}$ & $\begin{array}{l}\text { Data hasil wawancara bahwa dalam memahami kegiatan } \\
\text { pembelajaran yang mendidik, dapat disimpulkan } \\
\text { bahwasannya dalam menyusun rancangan pembelajaran } \\
\text { dapat dimulai dari menentukan pendekatan pembelajaran, } \\
\text { strategi pembelajaran, metode pembelajaran, teknik } \\
\text { pembelajaran, dan model pembelajaran yang cocok dengan } \\
\text { teori biologi. Hal ini bertujuan supaya kegiatan belajar } \\
\text { mengajar yang berlangsung dapat tersampaikan tujuan } \\
\text { materinya, baik untuk didalam kelas maupun di laboratorium } \\
\text { dan lapangan. Selain itu dalam proses penyusunan rancangan } \\
\text { pembelajaran maka harus memahami beberapa hal, } \\
\text { diantaranya RPP disusun untuk satu kali pertemuan atau }\end{array}$ \\
\hline
\end{tabular}




\begin{tabular}{|c|c|c|}
\hline & & $\begin{array}{l}\text { lebih, RPP yang dirancang harus jelas, dan juga harus } \\
\text { disesuaikan dengan tujuan pembelajaran. }\end{array}$ \\
\hline 5. & $\begin{array}{l}\text { Mengembangkan } \\
\text { potensi peserta didik }\end{array}$ & $\begin{array}{l}\text { Pengembangan potensi peserta didik ini dilakukan oleh } \\
\text { pendidik dengan mewujudkan suasana belajar dan proses } \\
\text { pembelajaran yang kondusif bagi peserta didik untuk } \\
\text { mengembangkan segenap potensi dirinya. Salah satunya } \\
\text { membantu peserta didik dalam proses pembelajaran dengan } \\
\text { menjelaskan kembali apa yang belum dipahami oleh peserta } \\
\text { didik, dan mencontohkannya, mengaitkan dengan kehidupan } \\
\text { sehari-hari yang lebih mudah dipahami oleh peserta didik } \\
\text { dan mengajak peserta didik untuk belajar sambil bermain. }\end{array}$ \\
\hline 6. & $\begin{array}{l}\text { Komunikasi dengan } \\
\text { peserta didik }\end{array}$ & $\begin{array}{l}\text { Komunikasi mahasiswa calon guru dengan peserta didik } \\
\text { dilakukan dengan cukup baik, sebab berkomunikasi dengan } \\
\text { peserta didik sangatlah penting bagi calon pendidik maupun } \\
\text { pendidik dalam proses pembelajaran, salah satunya yaitu } \\
\text { dapat menguasai kelas dengan baik dan dapat menjaga } \\
\text { partisipasi peserta didik pada saat pembelajaran berlangsung } \\
\text { dengan baik pula. }\end{array}$ \\
\hline 7. & Penilaian dan evaluasi & $\begin{array}{l}\text { Mahasiswa calon guru pendidikan biologi dalam evaluasi } \\
\text { dan penilaian masih belum maksimal, hal ini disebabkan } \\
\text { prihal evaluasi dan penilaian tergolong ribet dan susah } \\
\text { dilakukan oleh mahasiswa calon guru pendidikan biologi } \\
\text { terhadap peserta didik. }\end{array}$ \\
\hline N0. & $\begin{array}{c}\text { INDIKATOR } \\
\text { PERKEMBANGAN } \\
\text { PESERTA DIDIK } \\
\end{array}$ & KESIMPULAN \\
\hline 1. & $\begin{array}{l}\text { Kognitif, Afektif, dan } \\
\text { Psikomotorik }\end{array}$ & $\begin{array}{l}\text { Dalam menerapkan strategi pembelajaran, seorang calon } \\
\text { guru atau pendidik harus memahami peserta didik yang } \\
\text { memiliki tingkatan intelektual yang rendah, sedang, ataupun } \\
\text { tinggi. Disisi lain juga harus paham dalam pengaplikasian } \\
\text { strategi tersebut, sehingganya dalam proses pembelajaran } \\
\text { peserta didik dapat menikmati pembelajaran yang sedang } \\
\text { berlangsung. Kemudian dalam mengindentifikasi dan } \\
\text { menetapkan spesifikasi dan kualifikasi hasil serta sasaran } \\
\text { yang harus dicapai calon pendidik menggunakan pendekatan }\end{array}$ \\
\hline
\end{tabular}




\section{Data hasil dari instrumen dokumentasi}

pembelajaran yang telah ditetapkan, selanjutnya diturunkan ke dalam strategi pembelajaran, kemudian hasil sasaran yang harus dicapai disesuaikan dengan tujun pembelajaran. Mahasiswa calon guru atau pendidik dalam memilih media pembelajaran dengan cara mempertimbangkan materi, peserta didik, dan fasilitas serta tampilan menarik dalam pengonsepan media pembelajaran. Cara mengevalusi peserta didik dari aspek kognitif yakni dengan cara tes formatif dan sumatif berupa pilihan ganda dan esai, aspek afektif dan psikomotorik dengan menggunakan penilaian non tes misalnya pengamatan langsung atau observasi.

RPP yang disusun oleh informan akan disortir untuk mengetahui informan mana saja yang melampirkan lembar evaluasi peserta didik dalam aspek kognitif, aspek afektif dan aspek psikomotorik. Dari pengumpulan RPP mahasiswa calon guru pendidikan biologi didapatkan sebanyak 21 orang yang melampirlan lembar evaluasi peserta didik. Sebanyak 20 orang yang melampirkan lembar evaluasi aspek kognitif peserta didik, 20 mahasiswa lainnya melampirkan lembar evaluasi aspek afektif pada peserta didik, dan 21 mahasiwa lainnya melampirkan lembar evaluasi aspek psikomotorik pada peserta didik. Kemudian sebanyak 7 orang tidak melampirkan lembar evaluasi aspek kognitif, aspek afektif, dan aspek psikomotorik.

\section{Tabel 3}

Data Hasil Uji Kompetensi Pedagogik Mahasiswa Calon Guru Pendidikan Biologi UIN Raden Intan Lampung

\begin{tabular}{|c|c|c|c|}
\hline No. & $\begin{array}{l}\text { INDIKATOR KOMPETENSI } \\
\text { PEDAGOGIK }\end{array}$ & NO. SOAL & RATA-RATA \\
\hline 1. & Menguasai karakteristik peserta didik & $1,2,3$ & 47,62 \\
\hline 2. & $\begin{array}{l}\text { Menguasai teori belajar dan prinsip-prinsip } \\
\text { pembelajaran yang mendidik }\end{array}$ & $4,5,6,7,8,9$ & 62,5 \\
\hline 3. & Mengembangkan kurikulum & $\begin{array}{c}10,11,12,13,14,15 \\
, 16,17\end{array}$ & 38,39 \\
\hline 4. & Kegiatan pembelajaran yang mendidik & $\begin{array}{c}18,19,20,21,22,23 \\
, 24,25,26\end{array}$ & 56,75 \\
\hline 5. & Mengembangkan potensi peserta didik & $27,28,29$ & 41,67 \\
\hline 6. & Komunikasi dengan peserta didik & $30,31,32,33,34,35$ & 62,5 \\
\hline 7. & Penilaian dan evaluasi & $\begin{array}{c}36,37,38,39,40,41 \\
, 42,43,44\end{array}$ & 51,2 \\
\hline \multicolumn{3}{|c|}{ Rata-rata } & 51,52 \\
\hline
\end{tabular}




\section{Profil kompetensi pedagogik mahasiswa calon guru biologi di UIN Raden Intan Lampung}

Profil kompetensi pedagogik mahasiswa calon guru pendidikan biologi UIN Raden Intan Lampung didapat dari berbagai macam instrumen yang dapat mencerminkan kemampuan mahasiswa calon guru pendidikan biologi. Instrumen tersebut diantaranya : Lembar observasi yang diisi oleh peneliti, lembar wawancara yang dilakukan dengan mahasiswa calon guru pendidikan biologi UIN Raden Intan Lampung, dokumen berupa Rencana Pelaksanaan Pembelajaran (RPP), dan lembar tes Uji Kompetensi Guru (UKG). Penjelasan mengenai kompetensi pedagogik akan dipaparkan sebagai berikut:

\section{Memahami karakteristik peserta didik}

Berdasarkan tabel 1 data hasil observasi, mengenai pemahaman mahasiswa calon guru pendidikan biologi terhadap karakteristik peserta didik dapat diketahui sebesar 65,48, artinya dalam kriteria cukup. Kemudian didukung dari tabel 2 data hasil wawancara yang sudah dilakukan menunjukkan kesimpulan bahwa dalam memahami karakteristik peserta didik yaitu dengan cara pendekatan secara intensif, kemudian mengamati tingkah laku peserta didik saat proses pembelajaran berlangsung, saat sedang berdiskusi, tugas kelompok, ketika diberi kesempatan bertanya, menjawab atau memberi kesimpulan terkait materi yang diajarkan. Selanjutnya pada tabel 3 data hasil uji kompetensi guru dalam pemahaman karakteristik peserta didik menunjukan kurang, jika dikonversikan dalam bentuk angka yakni sebesar 47,62. Oleh sebab itu, penting sekali seorang mahasiswa calon guru/ pendidik memperhatikan pemahaman dalam kompetensinya, khususnya dalam mempersiapkan kemampuannya untuk menjadi seorang pendidik. Sebab hal ini juga akan dapat menunjang dalam memaksimalkan proses pembelajaran.

Seorang calon guru/ pendidik harus mengetahui dan memahami karkteristik peserta didiknya, sebab ini merupakan unsur yang sangat penting dalam proses pembelajaran, karena setiap peserta didik memiliki kemampuan dan karakter yang berbeda-beda. Menurut hamzah, karakteristik peserta didik merupakan aspek atau kualitas perseorangan peserta didik yang 
terdiri dari minat, sikap, motivasi belajar, gaya belajar, kemampuan berpikir, dan kemampuan awal yang dimiliki (Irwantoro and Suryana, 2016).

\section{Menguasai teori belajar dan prinsip-prinsip pembelajaran yang mendidik}

Berdasarkan hasil observasi pada tabel 1 pada teori belajar dan prinsip-prinsip pembelajaran yang mendidik menunjukan hasil sebesar 48,57 hal ini menunjukan bahwa mahasiswa calon guru pendidikan biologi tergolong kurang. Pamahaman terhadap teori dan prinsip-prinsip pembelajaran dipandang penting dikarenakan pembelajaran hakikatnya diselenggarakan calon pendidik/ pendidik disesuaikan dengan tingkat perkembangan yang dimiliki peserta didik. Salah satu teori Peaget yang dijelaskan berkaitan erat dengan tingkat perkembangan intelektual peserta didik, mulai dari tahap sensori motorik, praoperasional, operasional kongkrit, dan operasional formal. Peaget percaya bahwa manusia secara genetik serupa dan berbagi banyak pengalaman lingkungan yang sama (Nugraha and Ferisa, 2017). Hal tersebut mengisyaratkan bahwa pentingnya seorang calon pendidik dalam menguasai teori dan prinsip-prinsip pembelajaran yang mendidik.

Kemudian pada tabel 2 hasil wawancara yang telah dilakukan dapat disimpulkan bahwasannya mahasiswa calon guru pendidikan biologi dalam pemahamannya terhadap teori belajar dan prinsip-prinsip pembelajaran mengatakan satu kesatuan yang saling berhubungan. Cara untuk memahami teori dan prinsip pembelajaran dikaitkan dengan tujuan yang sebenarnya akan dicapai dalam pembelajaran itu sendiri. Mahasiswa calon guru dalam mengaplikasikan dan segi pemahaman memiliki keselarasan yang cukup, hal ini didukung dari tabel 3 hasil uji kompetensi guru yang telah dilakukan menunjukan hasil 62,5.

\section{Mengembangkan kurikulum}

Berdasarkan hasil observasi pada tabel 1 yang telah dilakukan, dapat diketahui pada mahasiswa calon guru yang menyediakan RPP dan melaksanakan pembelajaran sesuai dengan kurikulum sebesar 75. Selanjutnya pada tabel 2 hasil wawancara dalam penelitian ini mahasiswa calon guru dalam proses pembelajaran didalam kelas menyediakan RPP dan melaksanakan kegiatan pembelajaran sesuai isi serta mengkaitkannya dengan konteks kehidupan sehari-hari peserta didik. Berkaitan dalam pembelajaran, kurikulum menjadi 
sangat penting lantaran bagi pendidik maupun calon pendidik kurikulum menjadi sebuah keharusan yang harus dipahami maupun diaplikasikan dalam proses pembelajaran. Kemudian pada tabel 3 uji kompetensi guru pada mahasiswa calon guru didapatkan menunjukkan hasil yang masih kurang, jika dikonversikan dalam bentuk angka sebesar 38.39. Penting sekali seorang mahasiswa calon guru/ pendidik memperhatikan pemahaman dalam kompetensi guru dan selalu meningkatkan kompetensinya guna mempersiapkan dirinya untuk menjadi guru/ pendidik yang ideal, sebab hal ini juga akan dapat menunjang kemaksimalan dalam proses mengaplikasikan pembelajaran.

\section{Kegiatan pembelajaran yang mendidik}

Berdasarkan tabel 1 data hasil observasi, mengenai pemahaman mahasiswa calon guru pendidikan biologi terhadap kegiatan pembelajaran yang mendidik dapat diketahui sebesar 56,43, hal ini menunjukkan kategori cukup dalam pengaplikasian proses pembelajaran. Kemudian dari tabel 2 data hasil wawancara bahwa dalam memahami kegiatan pembelajaran yang mendidik, dapat disimpulkan bahwasannya dalam menyusun rancangan pembelajaran dapat dimulai dari menentukan pendekatan pembelajaran, strategi pembelajaran, metode pembelajaran, teknik pembelajaran, dan model pembelajaran yang cocok dengan teori biologi. Hal ini bertujuan supaya kegiatan belajar mengajar yang berlangsung dapat tersampaikan tujuan materinya, baik untuk didalam kelas maupun di laboratorium dan lapangan. Selain itu dalam proses penyusunan rancangan pembelajaran maka harus memahami beberapa hal, diantaranya RPP disusun untuk satu kali pertemuan atau lebih, RPP yang dirancang harus jelas, dan juga harus disesuaikan dengan tujuan pembelajaran. Selanjutnya didukung dari hasil penelitian pada tabel 3 data hasil uji kompetensi guru menunjukan cukup, dan jika dikonversikan dalam bentuk angka yakni sebesar 56,75.

Hal di atas tentunya menjadi sangat penting untuk selalu ditingkatkan, sebab seperti yang termaktub di dalam pasal 1 ayat 1 UU No. 20/ 2003 dapat dikatakan bahwa seorang pendidik dalam pembelajaran yang mendidik harus melakukan usaha sadar dan terencana untuk mewujudkan suasana belajar dan proses pembelajaran agar peserta didik secara aktif mengembangkan potensi dirinya untuk memiliki kekuatan spiritual keagamaan, 
pengendalian diri, kepribadian, kecerdasan, akhlak mulia, serta keterampilan yang diperlukan dirinya (Irwantoro and Suryana, 2016).

\section{Mengembangkan potensi peserta didik}

Berdasarkan tabel 1 data hasil observasi pada mengembangkan potensi peserta didik menunjukkan cukup, jika dikonversikan dalam bentuk angka yakni sebesar 51,19. Kemudian dari tabel 2 data hasil wawancara setelah dilakukan penelitian dapat disimpulkan bahwa pengembangan potensi peserta didik ini dilakukan oleh pendidik dengan mewujudkan suasana belajar dan proses pembelajaran yang kondusif bagi peserta didik untuk mengembangkan segenap potensi dirinya. Salah satunya membantu peserta didik dalam proses pembelajaran dengan menjelaskan kembali apa yang belum dipahami oleh peserta didik, dan mencontohkannya, mengkaitkan dengan kehidupan sehari-hari yang lebih mudah dipahami oleh peserta didik dan mengajak peserta didik untuk belajar sambil bermain. Selanjutnya pada tabel 3 data hasil uji kompetensi guru terhadap pemahaman mengenai mengembangkan potensi peserta didik menunjukan kurang, yakni sebesar 41,67. Hal ini menunjukkan bahwa penting sekali seorang mahasiswa calon guru/ pendidik memperhatikan pemahaman dalam kompetensinya, khususnya dalam mempersiapkan kemampuannya untuk menjadi seorang pendidik. Sebab hal ini juga akan dapat menunjang kemaksimalan dalam proses mengaplikasikan pembelajaran.

\section{Komunikasi dengan peserta didik}

Berdasarkan tabel 1 data hasil observasi pada komunikasi dengan peserta didik menunjukkan cukup yakni sebesar 55,71. Kemudian dari tabel 2 data hasil wawancara setelah dilakukan penelitian dapat disimpulkan bahwa komunikasi mahasiswa calon guru dengan peserta didik dilakukan dengan cukup baik, sebab berkomunikasi dengan peserta didik sangatlah penting bagi calon pendidik maupun pendidik dalam proses pembelajaran, salah satunya yaitu dapat menguasai kelas dengan baik dan dapat menjaga partisipasi peserta didik pada saat pembelajaran berlangsung dengan baik pula. Selanjutnya didukung dari tabel 3 data hasil uji kompetensi guru terhadap pemahaman mengenai komunikasi dengan peserta didik menunjukan sebesar 62,5. 
Wiranto Aris Munandar dalam pidato apresiasi besar guru ITB mengatakan bahwa tantangan bagi calon pendidik dan pendidik adalah bagaimana dapat menjelaskan materi pembelajaran dengan baik, memberikan yang esensial dengan cara yang menarik, percaya diri dan membangkitkan motivasi para peserta didiknya (Irwantoro and Suryana, 2016). Hal tersebut menunjukkan bahwa komunikasi dan interaksi dengan peserta didik sangat menentukan efektivitas dan mutu pembelajaran.

\section{Penilaian dan evaluasi}

Berdasarkan tabel 1 data hasil observasi pada mahasiswa calon guru pendidikan biologi mengenai pemahamannya terhadap penilaian dan evaluasi peserta didik menunjukkan kurang, yakni jika dikonversikan dalam bentuk angka sebesar 48,81. Kemudian dari tabel 2 data hasil wawancara setelah dilakukan penelitian dapat disimpulkan bahwa masih belum maksimal, mahasiswa calon guru pendidikan biologi dalam evaluasi dan penilaian, hal ini disebabkan prihal evaluasi dan penilaian tergolong ribet dan susah dilakukan oleh mahasiswa calon guru pendidikan biologi terhadap peserta didik.

Padahal terkait evaluasi dan penilaian ini sangat penting, menurut Arikunto, bagi peserta didik dapat mengetahui sejauh mana telah berhasil mengikuti pelajaran yang diberikan oleh pendidik/ guru, apakah hasilnya memuaskan atau tidak memuaskan. Bagi guru, dapat mengetahui para peserta didik yang sudah dan yang belum menguasai bahan pelajaran, tepat atau tidak materi pembelajaran yang disampaikan, dan metode yang digunakan. Bagi sekolah, dapat mengetahui apakah kondisi belajar yang diciptakan oleh sekolah sudah sesuai dengan harapan atau belum, dan apakah yang dilakukan oleh sekolah sudah memenuhi standar atau belum (Irwantoro and Suryana, 2016). Selanjutnya dari tabel 3 data hasil uji kompetensi guru pada pemahaman terkait penilaian dan evalusi menunjukan sebesar 51,2 artinya masih tergolong cukup.

\section{Pemahaman perkembangan peserta didik oleh mahasiswa calon guru biologi di UIN Raden Intan Lampung}

Berdasarkan hasil observasi pada tabel 1 pada pemahaman perkembangan peserta didik oleh mahasiswa calon guru pendidikan biologi pada aspek kognitif, aspek afektif, dan 
psikomotorik menunjukan dalam kategori cukup, jika dikonversikan dalam bentuk angka hasilnya sebesar 55,95. Kemudian pada tabel 2 hasil wawancara yang telah dilakukan dapat diambil kesimpulan bahwasannya mahasiswa calon guru pendidikan biologi dalam pemahamannya prihal evaluasi dan penilaian masih tergolong cukup. Kemudian pada hasil data instrumen dokumentasi yakni RPP yang telah disusun oleh informan setelah disortir informan mana saja yang melampirkan lembar evaluasi peserta didik dalam aspek kognitif, aspek afektif dan aspek psikomotorik dapat diketahui bahwa dari RPP mahasiswa calon guru pendidikan biologi didapatkan sebanyak 21 orang yang melampirlan lembar evaluasi peserta didik. Sebanyak 20 orang yang melampirkan lembar evaluasi aspek kognitif peserta didik, 20 mahasiswa lainnya melampirkan lembar evaluasi aspek afektif pada peserta didik, dan 21 mahasiwa lainnya melampirkan lembar evaluasi aspek psikomotorik pada peserta didik. Kemudian sebanyak 7 orang tidak melampirkan lembar evaluasi aspek kognitif, aspek afektif, dan aspek psikomotorik. Hal ini sesuai dengan pendapat Asmani, bahwa pada diri seorang pendidik/ guru perlu ditumbuhkan kesadaran penguasaan terhadap perkembangan peserta didik, teknik evaluasi, penguasaan terhadap model-model dan metode pembelajaran disamping penguasaan mata pelajaran dan iptek yang berkaitan dengan pengajaran (Kalu, Rede and Asep, 2016).

Selain itu perlu dikatahui bahwasannya salah satu kompetensi yang harus dicapai oleh calon pendidik maupun pendidik ialah kompetensi pedagogik. Kompetensi pedagogik ialah kompetensi yang dimiliki oleh pendidik maupun calon pendidik yang berhubungan dengan pemahaman terhadap peserta didik serta pengelolaan pembelajaran (Irwantoro and Suryana, 2016). Salah satu capaian dari pedagogik adalah kemampuan pendidik dalam melaksanakan penilaian didalam kelas.

Dari pemaparan sebelumnya, tentang pemahaman perkembangan peserta didik oleh mahasiswa calon guru menunjukkan dalam kategori cukup, yakni 55,95. Artinya dalam hal ini, nilai tersebut masih tergolong tipis dan tampak kurus. Tentu saja, pemahaman perkembangan peserta didik oleh calon guru harus selalu ditingkatkan karena ini menjadi sangat penting sehingganya sebagai calon guru harus paham sejauh mana perkembangan peserta didiknya. Minimnya pengetahuan dan pemahaman calon guru mengenai 
perkembangan peserta didik akan menyulitkan kegiatan belajar mengajar, menentukan strategi pembelajaran, pemilihan media pembelajaran, dan evaluasi pembelajaran.

Menganalisis hubungan kompetensi pedagogik mahasiswa calon guru biologi di UIN Raden Intan Lampung dengan pemahaman terhadap perkembangan peserta didik, yang meliputi: persiapan kegiatan pembelajaran yang mendidik, pengembangan potensi peserta didik, dan komunikasi peserta didik

Pada kompetensi pedagogik setelah dilakukan penelitian, terkhusus kegiatan pembelajaran yang mendidik, mengembangkan potensi peserta didik, dan komunikasi dengan peserta didik setelah diambil rata-rata keseluruhan menunjukkan hasil sebesar 54,04 dalam kategori cukup. Sedangkan pada pemahaman perkembangan peserta didik oleh mahasiswa calon guru pendidikan biologi menunjukkan dalam kategori cukup, jika dikonversikan dalam bentuk angka setelah dirata-rata sebesar 55,95.

Dari hasil penelitian tersebut menunjukkan bahwa kompetensi pedagogik calon guru pendidikan biologi memiliki keterkaitan antara pemahaman seorang calon pendidik terhadap perkembangan peserta didiknya. Sehingga dapat ditarik asumsi dalam penafsiran terdapat hubungan antara kompetensi pedagogik guru terhadap pemahaman calon guru mengenai perkembangan peserta didiknya. Bahwa semakin baik kompetensi pedagogik mahasiswa calon guru, maka semakin baik pula pemahaman mahasiswa calon guru terhadap perkembangan peserta didiknya, sebaliknya jika semakin tidak baik kompetensi pedagogik mahasiswa calon guru, maka semakin tidak baik pula pemahaman mahasiswa calon guru terhadap perkembangan peserta didiknya.

\section{SIMPULAN}

Berdasarkan hasil penelitian dan pembahasan tentang kompetensi pedagogik mahasiswa calon guru Pendidikan Biologi UIN Raden Intan Lampung dan pemahaman perkembangan peserta didik, maka peneliti dapat menarik kesimpulan sebagai berikut:

1. Profil kompetensi pedagogik mahasiswa calon guru biologi di UIN Raden Intan Lampung menunjukkan kriteria cukup dengan nilai rata-rata akhir sebesar 54,42. 
2. Pemahaman perkembangan peserta didik oleh mahasiswa calon guru biologi di UIN Raden Intan Lampung menunjukkan kriteria cukup dengan nilai rata-rata akhir sebesar 55,95 .

3. Hubungan kompetensi pedagogik mahasiswa calon guru biologi di UIN Raden Intan Lampung dengan pemahaman terhadap perkembangan peserta didik, yang meliputi: persiapan kegiatan pembelajaran yang mendidik, pengembangan potensi peserta didik, dan komunikasi peserta didik dapat ditafsirkan terdapat hubungan/ keterkaitan antara kompetensi pedagogik guru terhadap pemahaman calon guru mengenai perkembangan peserta didiknya. Bahwa semakin baik kompetensi pedagogik mahasiswa calon guru, maka semakin baik pula pemahaman mahasiswa calon guru terhadap perkembangan peserta didiknya, sebaliknya jika semakin tidak baik kompetensi pedagogik mahasiswa calon guru, maka semakin tidak baik pula pemahaman mahasiswa calon guru terhadap perkembangan peserta didiknya.

\section{DAFTAR PUSTAKA}

Hidayah, R. (2009) Psikologi Pengasuh Anak. Malang: UIN Malang Press.

Irwantoro, N. and Suryana, Y. (2016) Kompetensi Pedagogik. Sidoarjo: Genta Group Production.

Kalu, M. R., Rede, A. and Asep, H. (2016) 'Kompetensi Pedagogik Dan Profesional Guru Sekolah Dasar Yang Tersertifikasi Pada Pembelajaran Sains', 5(3).

Kemendikbud (2020) Neraca Pendidikan

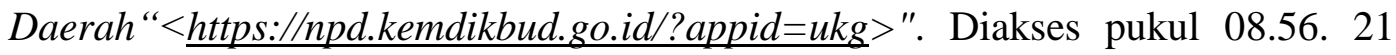
Agustus 2020.

Musfah, J. (2018) Manajemen Pendidikan Aplikasi, Strategi, dan Inovasi. Jakarta: Prenadamedia Group.

Nugraha, F. and Ferisa, D. (2017) 'Analisis Penguasaan Teori Belajar Dan Prinsip-Prinsip Pembelajaran Guru Di SDN 1 NAGARASARI’, 1(2).

Sagala, S. (2009) Kemampuan Profesional Guru dan Tenaga Kependidikan (Pemberdayaan Guru Tenaga Kependidikan dan Masyarakat dalam Manejemen Sekolah). Bandung: Alfabeta. 
Sugiono (2011) Metode Penelitian Pendidikan (Pendekatan Kuantitatif, Kualitatif, dan $R \& D)$. Bandung: Alfabeta.

Sukmawati, R. (2019) 'Analisis Kesiapan Mahasiswa Menjadi Calon Guru Profesional Berdasarkan Standar Kompetensi Pendidik', Jurnal Analisa, 5(1). doi: 10.15575/ja.v5i1.4789.

Sunarto and Hartono, A. (1995) Perkembangan Peserta Didik. Jakarta: Rineka Cipta.

Sutirna (2013) Perkembangan dan Pertumbuhan Peserta Didik. Yogyakarta: CV Andi Offset.

Tyagita, B. P. A. and Iriani, A. (2018) 'Strategi Peningkatan Kompetensi Pedagogik Guru Untuk Meningkatkan Mutu Sekolah', Kelola: Jurnal Manajemen Pendidikan, 5. doi: 10.24246/j.jk.2018.v5.i2.p165-176. 